УДК 621.35

DOI https://doi.org/10.32838/2663-5941/2020.1-2/17

Штефан В.В.

Національний технічний університет «Харківський політехнічний інститут»

Булгакова А.C.

Національний технічний університет «Харківський політехнічний інститут»

Пойманов А.Д.

Національний технічний університет «Харківський політехнічний інститут»

\title{
Лещенко С.A.
}

Національний технічний університет «Харківський політехнічний інститут»

\section{ПЕРСПЕКТИВНІ ЕЛЕКТРОДНІ МАТЕРІАЛИ ДЛЯ ПАЛИВНИХ ЕЛЕМЕНТІВ}

У наш час актуальним є напрям електрохімії - одержання багатокомпонентних осадів методом електроосадження. До таких осадів відносять не тільки бінарні, тернарні сплави або сплави, удосконалені лігандами, але й композиџійні покриття. Насамперед композииійні матеріали є ефективними у використанні в багатьох сферах діяльності зв'язку із широким спектром функиіональних властивостей: хімічна стійкість, висока міцність, електрокаталітична активність, стійкість до зношування. Також такі покриття можуть використовуватися для підвищення температурної та механічноі витривалості відповідальних деталей машин, які праџюють в агресивних середовищах, при виробниитві електричних контактів $і$ захисту деталей від корозії.

У роботі наведені результати дослідів перспективних електродних матеріалів для паливних елементів на основі композичійного покриття Со-Mo-TiO ${ }_{2}$, саме вивчення каталітичної активності композииійного осаду для реакиії виділення водню в різних середовищах. Гальванічні осади були одержані на мідних зразках з удосконаленого аміачно-трилонатного електроліту, модифікованого порошком

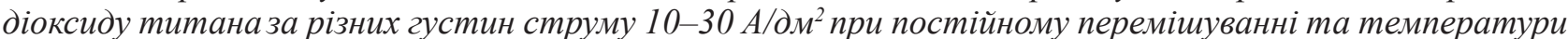
$70^{\circ}$ C. Представлений варіант вирішення проблеми, пов'язаної із корозійною нестійкістю бінарного сплаву Со-Мо в кислих середовищах. Наведені результати, отримані методом поляризаційних залежностей у таких розчинах: гідроксид натрію, сульфат натрію, сірчана кислота із концентрацією 0,1 моль/л і гідроксид натрію із кониентрачією 1 моль/л.

Композииійне покриття Со-Мо-ТіО активністю, що робить такий осад перспективним матеріалом для застосування у сфері паливних елементів. Композиція Со-Мо- $\mathrm{TiO}_{2}$ є досить ефрективним каталізатором для реакиії виділення водню.

Ключові слова: композиційне покриття, кобальт, молібден, діоксид титану, каталітична активність.

Постановка проблеми. Одержання осадів необхідного складу, структури і відповідних властивостей відіграє значну роль для сучасної техніки та технології. Розвиток нових напрямів застосування покриттів на основі тугоплавких металів пов'язаний із тим, що електролітичне осадження багатокомпонентних осадів дозволяє отримати абсолютно нові поліпшені властивості для матеріалів [1-4]. Гальванічні покриття Co-Mo [4-9] і композиційні Co-Mo-TiO $є$ є перспективними матеріалами для використання в багатьох сферах промисловості. Вони мають більш високі антикорозійні властивості, твер- дість, зносо- і жаростійкість, володіють магнітною проникністю, каталітичною активністю, надпровідністю, пайкою, пружністю [10-16]. Для значного зниження рівня залишкових напружень додають $\mathrm{TiO}_{2}$. Захисні плівки, утворені $з$ умістом $\mathrm{TiO}_{2}$ мають технологічні маркери (термостійкість, суцільність, однорідність по товщині і складу, адгезія) і експлуатаційні, необхідні для забезпечення функціональних специфічних властивостей одержаних осадів. Також завдяки вмісту діоксиду титана зростає корозійна стійкість у композиційного покриття Co-Mo- $\mathrm{TiO}_{2}[17]$. 
Застосування тугоплавких металів спрямоване на максимально ефективне використання їх природних властивостей. Висока корозійна стійкість i каталітична активність композиції Co-Mo-TiO роблять такі осади корисними навіть для застосування у сфері паливних елементів. адже покриття $\mathrm{Co}-\mathrm{Mo}-\mathrm{TiO}_{2} є$ досить результативним каталізаторам, який прискорює електрохімічні реакції, що забезпечують ефективне виділення водню.

Методика експерименту. Для осадження композиційних покриттів $\mathrm{Co}-\mathrm{Mo}-\mathrm{TiO}_{2}$ використовували зразки, виготовлені з міді, площа яких

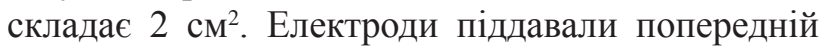
обробці, технологічний процес якої передбачає послідовне проведення ряду операцій: механічна очистка від технологічних забруднень і продуктів корозії за допомогою наждачного паперу; промивка в проточній і дистильованій воді; сушка. Травлення проводили в розчині азотної та сульфатної кислот із подальшим промиванням зразків.

Під час проведення досліджень використовували електрохімічну комірку. Для варіювання інтенсивності перемішування розчинів і забезпечення їх сталої температури використовували магнітну мішалку марки ММ-5 і джерело постійного струму Б5-44 [18]. Зразки після травлення завішували до електрохімічної комірки $з$ аміачнотрилонатним електролітом [19] та анодом - пла- тиновою сіткою. Температура електроліту підтримувалася в межах $70^{\circ} \mathrm{C}$, осадження проводились при постійному перемішуванні. Покриття одержували при густині струму 10; 20; 30 А/дм² і рН 5. Для підтримання $\mathrm{pH}$ додавали $\mathrm{H}_{2} \mathrm{SO}_{4}$ та $\mathrm{NaOH}$. Після завершення осадження катоди промивали дистильованою водою та сушили на повітрі.

Електрокаталітичні властивості електродних матеріалів оцінювали за допомогою поляризаційних залежностей виділення водню, отриманих у розчинах $1 \mathrm{M} \mathrm{NaOH}, 0,1 \mathrm{M} \mathrm{NaOH}, 0,1 \mathrm{M} \mathrm{H}_{2} \mathrm{SO}_{4} \mathrm{i}$ $0,1 \mathrm{M} \mathrm{Na}_{2} \mathrm{SO}_{4}$. Швидкість розгортки потенціалу $3 \mathrm{mB} / \mathrm{c}$. Для проведення експериментів використовували трьохелектродну комірку з хлорсрібним електродом у тому ж розчині. В якості допоміжного електрода використовували платиновий дріт.

Виклад основного матеріалу дослідження. 3 метою порівняння каталітичної активності одержаного осаду Co-Mo- $\mathrm{TiO}_{2} 3$ різною густиною струму були одержані катодні поляризаційні залежності виділення водню у розчинах $1 \mathrm{M}$ $\mathrm{NaOH}, 0,1 \mathrm{M} \mathrm{NaOH}, 0,1 \mathrm{M} \mathrm{H}_{2} \mathrm{SO}_{4}$ та $0,1 \mathrm{M} \mathrm{Na}_{2} \mathrm{SO}_{4}$.

На рисунку 1 наведенні одержані потенціодинамічні катодні поляризаційні залежності густини струму від перенапруги у реакції виділення водню в різних середовищах на композиційному осаді $\mathrm{Co}-\mathrm{Mo}-\mathrm{TiO}_{2}$ із різною густиною струму осадження.

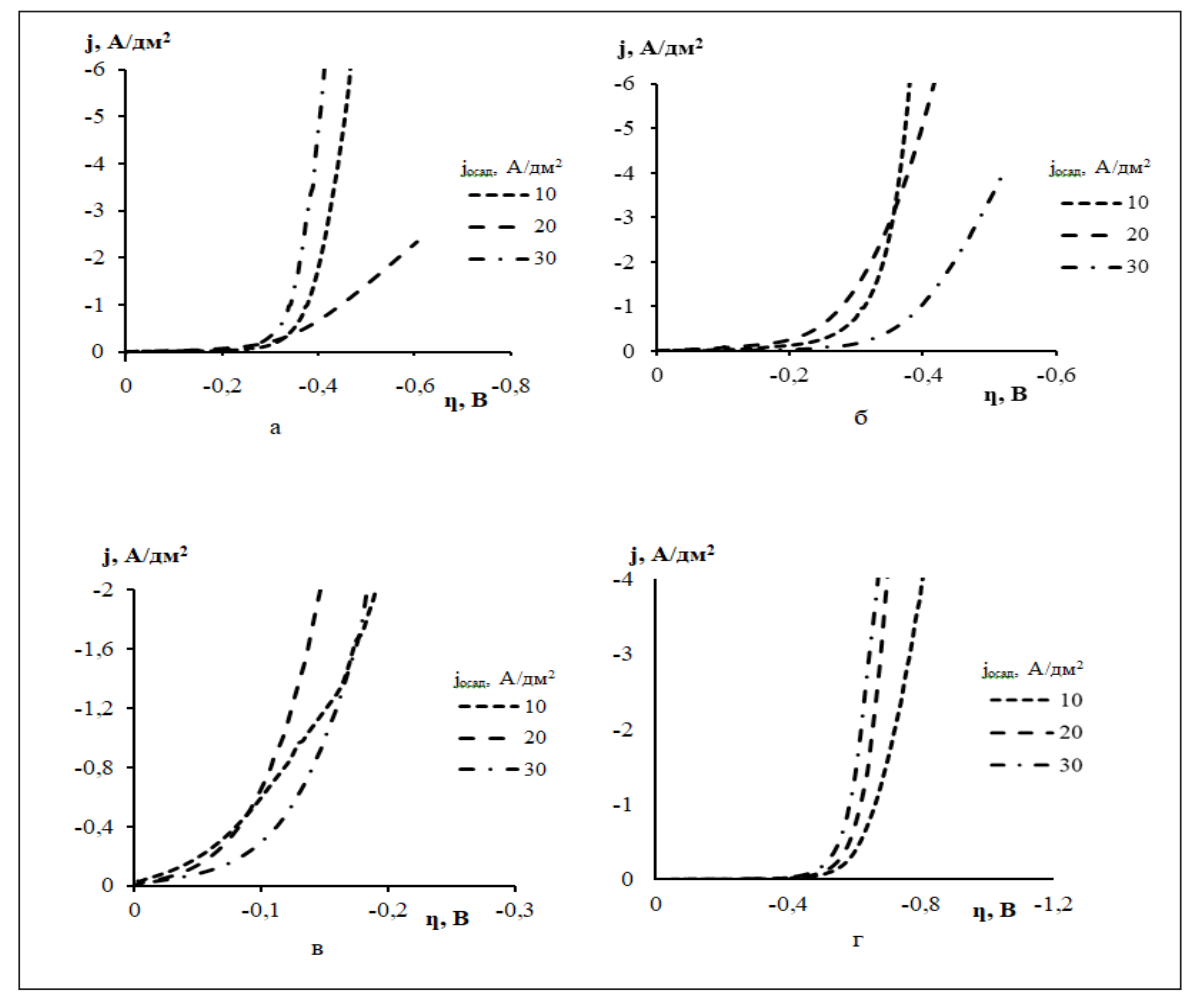

Рис. 1. Залежність густини струму від перенапруги виділення водню на осаді Со-Мо-TiO $:$ а) 0,1M NaOH; б) $1 \mathrm{M} \mathrm{NaOH}$; в) 0,1 $\mathrm{M} \mathrm{H}_{2} \mathrm{SO}_{4}$; г) $0,1 \mathrm{M} \mathrm{Na}_{2} \mathrm{SO}_{4}$ 
Проведена оцінка каталітичної активності покриттів у водневій реакції виділення водню за значенням перенапруги при $\mathrm{j}=1 \mathrm{~A} /$ дм² $^{2}$. У лужному розчині композиційне покриття $\mathrm{Co}-\mathrm{Mo}_{-} \mathrm{TiO}_{2}$ осаджене при $20 \mathrm{~A} /$ дм$^{2}$ має найменше значення перенапруги 0,274 В, що вказує на найвищу каталітичну активність. Зменшення концентрації розчину $\mathrm{NaOH} 31$ до 0,1 моль/л призводить до збільшення перенапруги. У сульфатних розчинах каталітична активність одержаного осаду інша, ніж у 0,1 та 1 моль/л розчинах $\mathrm{NaOH}$. У розчині $\mathrm{H}_{2} \mathrm{SO}_{4}$ значення перенапруги мають показники порядку 0,114-0,144 В, що свідчить про високу каталітичну активність композиції. У розчині $\mathrm{Na}_{2} \mathrm{SO}_{4}$ перенапруга висока, тобто каталітична активність покриття гірша, ніж для попередніх розчинів.
Спираючись на результати, отримані авторами у попередніх роботах, у яких досліджувалася каталітична активність покриття Со-Мо в таких само розчинах $0,1 \mathrm{M} \mathrm{NaOH} ; 1 \mathrm{M} \mathrm{NaOH}$; $0,1 \mathrm{M} \mathrm{H}_{2} \mathrm{SO}_{4} ; 0,1 \mathrm{M} \mathrm{Na}_{2} \mathrm{SO}_{4}$. Можна стверджувати, що для розчинів $\mathrm{NaOH}$ доцільно використовувати композиційне покриття Co-Mo- $\mathrm{TiO}_{2}$, тому що їх каталітична активність вища, ніж у сплаву Co-Mo, про свідчить значення перенапруги.

Висновки. Аналіз отриманих даних дає змогу оцінити каталітичну активності композиційного покриття Co-Mo-TiO 2 у розчинах $0,1 \mathrm{M} \mathrm{NaOH} ; 1 \mathrm{M} \mathrm{NaOH} ; 0,1 \mathrm{M}$ $\mathrm{H}_{2} \mathrm{SO}_{4} ; 0,1 \mathrm{M} \mathrm{Na} \mathrm{SO}_{4}$. Композиція має більш високу каталітичну активність, ніж сплав Со-Мо для розчинів $\mathrm{NaOH}$. Для розчинів $\mathrm{H}_{2} \mathrm{SO}_{4}$ одержаний осад Co-Mo$\mathrm{TiO}_{2}$ має найменше значення перенапруги, внаслідок чого можна рекомендувати композиційне покриття як матеріал для паливних елементів.

\section{Список літератури:}

1. Subramania A., SathiyaPriya A.R., Muralidharan V.S. Electrocatalytic cobalt-molybdenum alloy deposits. International Journal of Hydrogen Energy. 2007. V. 32. P. 2843-2847.

2. Соколов А.Ю., Курбатов А.П., Уразалин А.К., Брайда В.Дж., Наурызбаев М.К. Получение кобальтмолибденовых сплавов из цитратного электролита. Горение и плазмохимия. 2008. Т. 6, № 4. С. 298-305.

3. Кузнецов В.В., Бондаренко 3.В., Пшеничкина Т.В., Морозова Н.В., Кудрявцев В.Н. Электроосаждение сплава Со-Мо из аммиачно-цитратного электролита. Электрохимия. 2007. № 43, Вып. 3. С. 367-372.

4. Громова В.А., Японцева Ю.С., Кублановский В.С., Дикусар А.И. Электроосаждение сплавов Со-Мо из цитратно-пирофосфатного электролита. УКР. ХИМ. ЖУРН. 2008. Т. 74, № 3. С. 44-48.

5. Shtefan V.V., Epifanova A.S., Koval'ova A.A., Bairachnyi B.I. Electrolytic Deposition of Highly Hard Coatings of a Cobalt-Molybdenum Alloy. MaterSci. 2017. V. 52. P. 1-8.

6. Gomez E., Pellicer E., Duch M., etc. Molybdenum Alloy Electrodeposits for Magnetic Actuation. Electrochim. Acta. 2006. V. 51. P. 3214-3222.

7. Coutsouradis D., Davin A., Lamberigts M. Cobalt-based superalloys for applications in gas turbines. Mater. Sci. Eng. 1987. V. 88. P. 11-19.

8. Yapontseva Yu.S., Kublanovsky V.S., Vyshnevskyi O.A. Electrodeposition of CoMoRe alloys from a citrate electrolyte. Journal of Alloys and Compounds. 2018. V. 766. P. 894-901.

9. Японцева Ю.С., Дикусар А.И., Кублановский В.С. Исследование состава, коррозионных и каталитических свойств сплавов Co-W, электроосажденных из цитратно-пирофосфатного электролита. Электронная обработка материалов. 2014. Т. 50, № 4. С. 49-55.

10. Громова В.А., Японцева Ю.С., Кублановский В.С. Сплави Со-Мо, електроосаджені із полілігандного електроліту. Тези доп. II Всеукр. наук.-практ. конф. молодихвчених. Київ, 2007. С. 88.

11. Kublanovsky V.S., YapontsevaYu.S. Electrocatalytic Properties of Co-Mo Alloys Electrodeposited from a Citrate-Pyrophosphate Electrolyte. Electrocatalysis. 2014. V. 5. P. 372-378.

12. Штефан В.В., Єпіфанова А.С., Кобзєв М.М., Метенканич М.М. Вольтамперометрія осадження сплаву Со-Мо. Вісник Начіонального технічного університету «ХПI». Серія: Хімічна технологія та екологія. 2017. №. 39. С. 80-83.

13. Shtefan V., Yepifanova A., Berezovskyi I., Shkolnikova T. Stady of morphology and microhardness of Co-Mo alloys films. XVI International conference on physics and technology of thin films and nanosystems: materials ICPTTFN-XVI. (Ivano-Frankivsk, 15-20 may 2017 yr.). Ivano-Frankivsk, 2017. P. 204.

14. Штефан В.В., Епифанова А.С., Мануйлов А.М., Кучма Ю.Ю., Канунникова Н.А. Вольтамперометрия $\mathrm{d}^{4}-\mathrm{d}^{10}$ металлов. Международная научно-техническая конференція "Современные электрохимические технологии и оборудование» : материалы докладов Международной научно-технической конференции «Современные электрохимические технологии и оборудование». (Минск, 24-25 ноября 2016 г.). Минск, 2016. C. 335.

15. Штефан В.В., Єпіфанова А.С., Метенканич М.М., Пойманов А.Д., Школьнікова Т.В. Механізм катодних реакцій осадження сплаву Со-Мо. Записки Таврійського начіонального університету ім. B.I. Вернадського. Сер.: Технічні науки. 2019. Т. 30(69), № 1, ч. 2. С. 51-56. 
16. Shtefan V.V., Smyrnov O.O., Bezhenko A.O., Epifanova A.S., Kanunnikova N.O., Metenkanych M.M., Knyazev S.A. Electrolytic Deposition of Corrosion of Cobalt-Molybdenum Alloys in Chloride Solutions. MaterSci. 2019. V. 54.4. P. 512-518.

17. Штефан В.В., Єпіфанова А.С., Метенканич М.М., Школьнікова Т.В., Школьнікова Т.В. Структурнофазовий склад композиційного сплаву Со-Мо- $\mathrm{TiO}_{2}$. Записки Таврійського національного університету ім. В.I Вернадського. Сер.: Технічні науки. 2019. Т. 30(69), № 2, ч. 2. С. 131-135.

18. Єпіфанова А.С., Штефан В.В. Електролітичне осадження сплаву кобальт-молібден. 10 Міжнародна науково-практична студентська конференція магістрантів : матеріали конферениії. (Харків, 05-08 квітня 2016 р.): у 3 ч. ч. 2. Харків : НТУ «ХПІ», 2016. С. 223.

19. Електроліт для нанесення покриття кобальт-молібдену: пат. 112925 Україна: МПК (2006.01) C25D 3/56, № а201307706; заяв. 20.04.2015; опубл. 10.11.2016, Бюл. № 21.

\section{Shtefan V.V., Bulhakova A.S., Poimanov A.D., Leshchenko S.A. PROSPECTIVE ELECTRICAL MATERIALS FOR FUEL ELEMENTS}

Nowadays, the direction of electrochemistry - receiving multicomponent precipitates by electrodeposition method has an actual character. Such sediments include not only binary, ternary alloys or alloys enhanced with ligands, but also composite coatings. First of all, composite materials are effective in many fields of activity due to their wide range of functional properties. Such as chemical resistance, high strength, electrocatalytic activity, wear resistance. Such coatings can also be used to increase the temperature and mechanical endurance of critical machine parts operating in harsh environments and in the manufacture of electrical contacts and protection of parts against corrosion.

This paper presents the results of experiments of promising electrode materials for fuel cells based on the composite $\mathrm{Co}-\mathrm{Mo}-\mathrm{TiO}_{2}$ coating. Namely, the study of the catalytic activity of the composite precipitate for the reaction of hydrogen evolution in different media. Electroplating sediments were obtained on copper samples from an improved ammonia-trilonate electrolyte modified with titanium dioxide powder at different current densities of 10-30 A/d ${ }^{2}$ with constant stirring and a temperature of $70^{\circ} \mathrm{C}$. A solution to the problem of corrosion instability of the Co-Mo binary alloy in acidic environments is presented. The results obtained by the method of polarization dependencies in the following solutions are presented: sodium hydroxide, sodium sulfate, sulfuric acid with a concentration of $0,1 \mathrm{~mol} / \mathrm{l}$ and sodium hydroxide with a concentration of $1 \mathrm{~mol} / \mathrm{l}$.

The Co-Mo-TiO $\mathrm{C}_{2}$ composite coating has considerable corrosion resistance and catalytic activity, which in turn makes this sediment a promising material for use in the fuel cell field. The Co-Mo-TiO' composition is a fairly effective catalyst for the hydrogen evolution reaction.

Key words: composite coating, cobalt, molybdenum, titanium dioxide, catalytic activity. 